\title{
Rayleigh-Ritz 法を用いた螺旋状厚肉円筒の自由振動解析 FREE VIBRATION ANALYSIS OF SPIRAL THICK CYLINDRICAL SHELLS USING THE RAYLEIGH-RITZ METHOD
}

\author{
板 倉 和 則* \\ Kazunori ITAKURA
}

\begin{abstract}
The derivation of fundamental equations about the free vibration of spiral thick cylindrical shells is presented in this paper. Firstly, the strain-displacement relationships is based on assumptions of the three-dimensional coordinate system. Then, the principle of virtual work for the vibration of spiral thick cylindrical shells is formulated with some numerical results using the Rayleigh-Ritz method by considering rotating inertia and shear deformation. The numerical results are compared with those which are in the literature and are obtained by finite element method, etc. The method presented in this paper is useful for analyzing free vibration of spiral thick cylindrical shells.
\end{abstract}

\section{Keywords: Free vibration, Spiral cylindrical thick shell, Rotating inertia, Rayleigh-Ritz Method}

自由振動，螺旋状厚肉円筒，回転慣性，レーレ・リッツ法

\section{1. はじめに}

螺旋を主軸とした形状は、螺旋階段、螺旋桁、曲管等、様々な 種類があり、そのような特殊な形状の振動解析には一般的には有 限要素法が用いられる。しかし、有限要素法では、㸚じれた板で さえも使用する剛性マトリックスの違いによって、固有円振動数 にかなりの差が生じることが指摘されている ${ }^{1)}$ 。そこで、本報告 では、曲がってねじれた螺旋状円筒の振動解析を Rayleigh-Ritz 法 を用いて行い、代表的な有限要素法であるアイソパラメトリック 型有限要素法による解析法と比較・検討を行う。

一般的には複雑な形状の自由振動解析には Rayleigh-Ritz 法はあ まり用いられない。これは、Rayleigh-Ritz 法が他の解析方法に比 べて精度が高いという反面、解析対象が単純な形状及び境界条件 を有する場合に限られるため汎用性が無いということがあげられ る。

前報告では、螺旋軸を主軸とし、微小変形理論を用いて螺旋状 厚肉円筒の三次元ひずみ一変位関係式を導いた。つぎに、 Kirchhoff-Love の仮定を用いて螺旋状薄肉円筒のひずみ一変位関 係式を導き、仮想仕事の原理及び Rayleigh-Ritz 法により片持ち螺 旋状薄肉円筒の自由振動解析を行い、無次元振動数パラメータ $\lambda$ 及び振動モードを求めた ${ }^{2)}$ 。さらに、高次ラグランジ型補間関数 を用いた三次元アイソパラメトリック要素及びアイソパラメトリ ックシェル要素 ${ }^{3)}$ によって片持ち螺旋状薄肉円筒の自由振動解析 を行い、結果を比較・検討した ${ }^{2)}$ 。

本報告では、前報告で求めた螺旋状厚肉円筒の三次元ひずみ一 変位関係式と、三次元の仮想仕事の原理及び Rayleigh-Ritz 法を用
いて螺旋状厚肉円筒の自由振動解析を行い、板厚の変化が及ぼす 無次元振動数パラメータ $\lambda$ 及び振動モードへの影響、また、前報 告の薄肉理論による解析法の適用限界等を調べることを目的とす る。

なお、曲がりやねじれを含んだ螺旋状薄肉及び厚肉円筒の自由 振動解析を行うことは、曲管等の振動性状を知るためには有効な ことと考える ${ }^{4)}$ 。また、円筒の自由振動解析例に関しては、直円 筒（長さ方向が真直ぐな円筒）、トーラス（曲がりを含んでいる円 筒）等は見かける ${ }^{5)}$ が、螺旋状円筒（曲がり、及び、ねじれを含 んでいる円筒）に関しては見たことがない。

\section{2. 解析方法}

\section{1 螺旋状円筒の形状}

まず、前報告 ${ }^{2)}$ に従って説明する。図 1 に示すように半径 $a$ の 円筒による底面の中心を点 $O$ とし、円筒の側面を時計回りに底面 との角度 $\alpha$ で上がっていく $x$ 軸を考える。その軸上の任意の点に おける接線方向の単位ベクトルを $\mathbf{i}_{1}$ 、円筒の半径方向の単位ベク トルを $\mathbf{i}_{2}$ とし、 $\mathbf{i}_{1} 、 \mathbf{i}_{2}$ と右手系をなし、両者に垂直な単位ベクトル を $\mathbf{i}_{3}$ とする。したがって $\mathbf{i}_{1} 、 \mathbf{i}_{2} 、 \mathbf{i}_{3}$ は局部座標系の単位ベクトルで あり、 $x$ 軸を移動するにつれて方向が変わる心゙クトルである。な お、図 1 に示寸ように螺旋状円筒は $x$ 軸を中心とし $\mathbf{i}_{2}-\mathbf{i}_{3}$ 方向面に 半径 $\mathrm{R}$ 、厚さ $\mathrm{t}$ を持つ。

\section{2 ひずみ一変位関係式}

円筒の中央面上における点 $\mathbf{P}$ の位置ベクトル $\mathbf{r}_{0}{ }^{\left({ }^{0}\right.}$ は螺旋座標 で表すと次式のようになる。ただし、全体座標の原点は $O$ 点に 
とっている。

$$
\begin{aligned}
\mathbf{r}_{0}^{(0)}= & \left(x \sin ^{2} \alpha\right) \mathbf{i}_{1}+(a+R \cos \theta) \mathbf{i}_{2} \\
& +(x \sin \alpha \cos \alpha+R \sin \theta) \mathbf{i}_{3}
\end{aligned}
$$

セレ・フレネの公式より $\mathbf{i}_{1} 、 \mathbf{i}_{2} 、 \mathbf{i}_{3}$ の間には次のような関係があ る。

$$
\begin{aligned}
& \frac{\partial \mathbf{i}_{1}}{\partial x}=-\kappa \mathbf{i}_{2} \\
& \frac{\partial \mathbf{i}_{2}}{\partial x}=\kappa \mathbf{i}_{1}-\tau \mathbf{i}_{3} \\
& \frac{\partial \mathbf{i}_{3}}{\partial x}=\tau \mathbf{i}_{2}
\end{aligned}
$$

螺旋軸の場合曲率 $\kappa$ 、漦じれ率 $\tau$ は次式で表される。

$$
\begin{gathered}
\kappa=\frac{a}{a^{2}+c^{2}}=\frac{1}{\omega} \cos \alpha \\
\tau=\frac{c}{a^{2}+c^{2}}=\frac{1}{\omega} \sin \alpha
\end{gathered}
$$$$
\text { ここで } \omega=\sqrt{a^{2}+c^{2}} \text { である。 }
$$

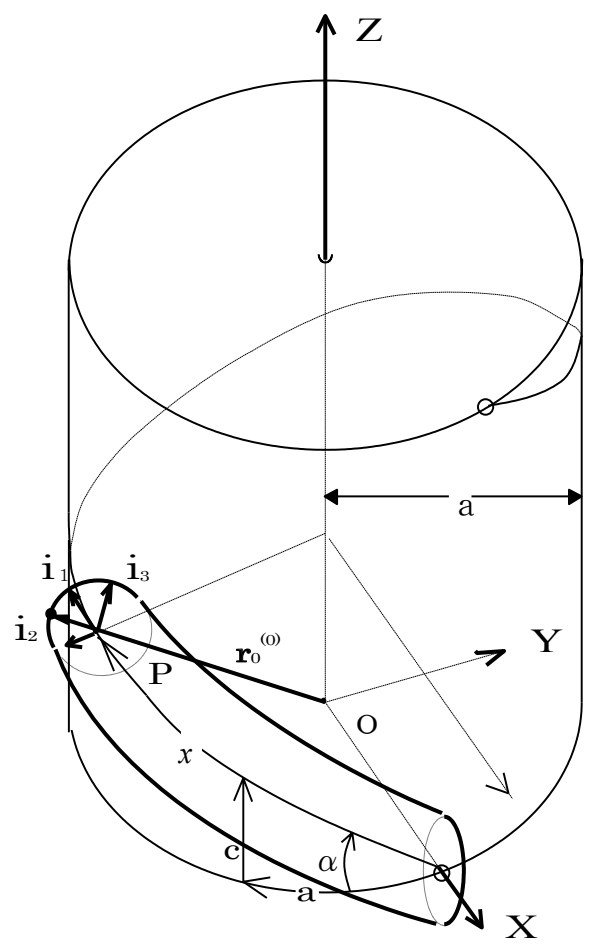

図 1 螺旋座標上の円筒

円筒の中央面上の基本ベクトル $\mathbf{a}_{1}, \mathbf{a}_{2}, \mathbf{a}_{3}$ は次のようになる。

$$
\begin{aligned}
\mathbf{a}_{1}= & \frac{\partial \mathbf{r}_{0}^{(0)}}{\partial x}=\left(1+\frac{R}{\omega} \cos \alpha \cos \theta\right) \mathbf{i}_{1} \\
& +\left(\frac{R}{\omega} \sin \alpha \sin \theta\right) \mathbf{i}_{2}-\left(\frac{R}{\omega} \sin \alpha \cos \theta\right) \mathbf{i}_{3} \\
\mathbf{a}_{2}= & \frac{\partial \mathbf{r}_{0}^{(0)}}{R \partial \theta}=(-\sin \theta) \mathbf{i}_{2}+(\cos \theta) \mathbf{i}_{3} \\
\mathbf{a}_{3}= & \frac{\mathbf{a}_{1} \times \mathbf{a}_{2}}{\left|\mathbf{a}_{1} \times \mathbf{a}_{2}\right|}=(-\cos \theta) \mathbf{i}_{2}+(-\sin \theta) \mathbf{i}_{3}
\end{aligned}
$$

円筒の中央面から距離 $z$ にある点の位置ベクトル $\mathbf{r}^{(0)}$ は

$$
\begin{aligned}
\mathbf{r}^{(0)} & =\mathbf{r}_{0}^{(0)}+z \mathbf{a}_{3} \\
& =\left(x \sin ^{2} \alpha\right) \mathbf{i}_{1}+\{a+(R-z) \cos \theta\} \mathbf{i}_{2} \\
& +\{x \sin \alpha \cos \alpha+(R-z) \sin \theta\} \mathbf{i}_{3}
\end{aligned}
$$

となる。

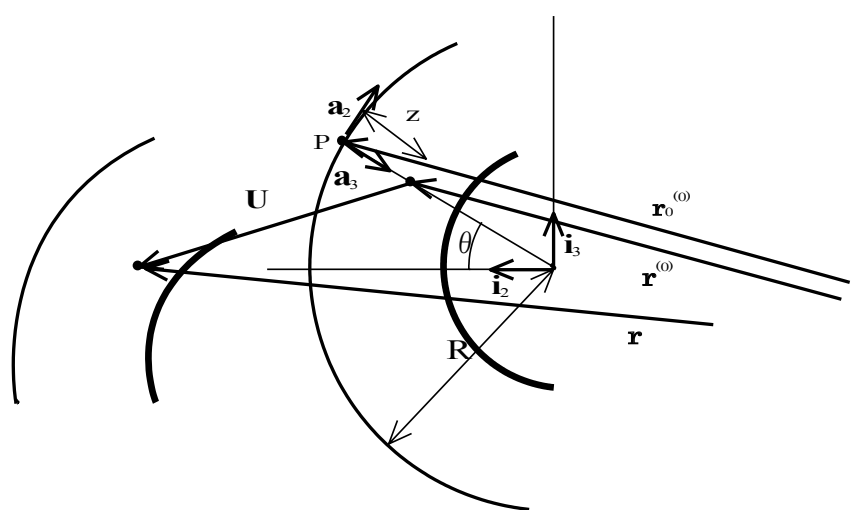

図 2 円筒の変形状態

図 2 に螺旋状円筒の変形状態を示す。なお、円弧の細線は変形前 後の中立面を、円弧の太線は変形前後の内側境界面を示している。

変位ベクトル $\mathbf{U}$ を中央面の基本ベクトルで表し、 $\mathbf{a}_{1} 、 \mathbf{a}_{2} 、 \mathbf{a}_{3}$ 方向 の成分を $U(x, \theta, z) 、 V(x, \theta, z) 、 W(x, \theta, z)$ とすると

$$
\mathbf{U}=U \mathbf{a}_{1}+V \mathbf{a}_{2}+W \mathbf{a}_{3}
$$

となり、変形後の任意点の位置ベクトル $\mathbf{r}$ は

$$
\mathbf{r}=\mathbf{r}^{(0)}+\mathbf{U}
$$

となる。

螺旋座標 $(x, \theta, z)$ におけるひずみ一変位関係式を、局部直交直線座 標系 $(\bar{x}, \bar{\theta}, \bar{z})$ に関するひずみ一変位関係式に変換する。そこで螺旋状 円筒の任意点において、局部直交直線座標 $(\bar{x}, \bar{\theta}, \bar{z})$ を設け、それぞれ の方向の単位ベクトルを $\mathbf{j}_{\mathbf{i}}(\mathrm{i}=1,2,3)$ とする。ここで、 $\mathbf{j}_{2}$ は $\mathbf{a}_{2}$ 方向、 $\mathbf{j}_{3}$ は $\mathbf{a}_{3}$ 方向、 $\mathbf{j}_{1}$ は $\mathbf{j}_{2} \times \mathbf{j}_{3}$ 方向である。よって $(\bar{x}, \bar{\theta}, \bar{z})$ 座標系における厚 肉円筒の三次元ひずみ一変位関係式が前報告では以下のように求め られている。

$$
\begin{aligned}
e_{11} & =\varepsilon_{\overline{x x}}=\frac{1}{1+\frac{R-z}{\omega} \cos \alpha \cos \theta}\left\{\frac{\partial U}{\partial x}\left(1+\frac{R}{\omega} \cos \alpha \cos \theta\right)\right. \\
+ & \frac{\partial U}{R \partial \theta} \cdot \frac{R}{\omega} \sin \alpha\left(1+\frac{R}{\omega} \cos \alpha \cos \theta\right)-V \frac{1}{\omega} \cos \alpha \sin \theta \\
\left.-W \frac{1}{\omega} \cos \alpha \cos \theta\right\} & \\
e_{22} & =\varepsilon_{\overline{\theta \theta}}=\frac{1}{1-\frac{z}{R}}\left(-\frac{\partial U}{R \partial \theta} \cdot \frac{R}{\omega} \sin \alpha+\frac{\partial V}{R \partial \theta}-W \frac{1}{R}\right) \\
e_{33} & =\varepsilon_{\overline{z z}}=\frac{\partial W}{\partial z}
\end{aligned}
$$




$$
\begin{aligned}
& 2 e_{12}=\varepsilon_{\overline{x \theta}}=\left[\frac{1+\frac{R}{\omega} \cos \alpha \cos \theta}{1-\frac{z}{R}}-\frac{\frac{R^{2}}{\omega^{2}} \sin ^{2} \alpha}{1+\frac{R-z}{\omega} \cos \alpha \cos \theta}\right] \frac{\partial U}{R \partial \theta} \\
& +\frac{1}{1+\frac{R-z}{\omega} \cos \alpha \cos \theta}\left(-\frac{\partial U}{\partial x} \cdot \frac{R}{\omega} \sin \alpha+\frac{\partial V}{\partial x}+\frac{\partial V}{R \partial \theta} \cdot \frac{R}{\omega} \sin \alpha\right) \\
& +U \frac{1}{\omega} \cos \alpha \sin \theta\left[\frac{1+\frac{R}{\omega} \cos \alpha \cos \theta}{1+\frac{R-z}{\omega} \cos \alpha \cos \theta}-\frac{1}{1-\frac{z}{R}}\right] \\
& 2 e_{13}=\varepsilon_{\overline{x z}}=\frac{1}{1+\frac{R-z}{\omega} \cos \alpha \cos \theta}\left\{\frac{\partial W}{\partial x}+\frac{\partial W}{R \partial \theta} \cdot \frac{R}{\omega} \sin \alpha\right. \\
& \left.+U\left(1+\frac{R}{\omega} \cos \alpha \cos \theta\right) \frac{1}{\omega} \cos \alpha \cos \theta\right\} \\
& +\frac{\partial U}{\partial z}\left(1+\frac{R}{\omega} \cos \alpha \cos \theta\right) \\
& 2 e_{23}=\varepsilon_{\bar{\theta}}=\frac{1}{1-\frac{z}{R}}\left(\frac{\partial W}{R \partial \theta}-U \frac{1}{\omega} \sin \alpha+V \frac{1}{R}\right)-\frac{\partial U}{\partial z} \cdot \frac{R}{\omega} \sin \alpha \\
& +\frac{\partial V}{\partial z}
\end{aligned}
$$

\section{3 応カ一ひずみ関係式}

等方性三次元弾性体の応力一ひずみ関係式は次のようになる。

$$
\{\sigma\}=[\mathrm{H}]\{\varepsilon\}
$$

ここでマトリックス $\{\sigma\},\{\varepsilon\},[\mathrm{H}]$ は次に示される。

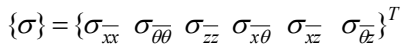

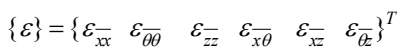$$
[\mathrm{H}]=\frac{E(1-v)}{(1+v)(1-2 v)}\left[\begin{array}{cccccc}
1 & \mathrm{H}_{1} & \mathrm{H}_{1} & 0 & 0 & 0 \\
& 1 & \mathrm{H}_{1} & 0 & 0 & 0 \\
& & 1 & 0 & 0 & 0 \\
& & & \mathrm{H}_{2} & 0 & 0 \\
& \text { sym. } & & & \mathrm{H}_{2} & 0 \\
& & & & & \mathrm{H}_{2}
\end{array}\right]
$$

$$
\mathrm{H}_{1}=\frac{v}{1-v}, \quad \mathrm{H}_{2}=\frac{1-2 v}{2(1-v)}
$$

$$
\text { ここに、Eはヤング率、vはポアソン比である。 }
$$

\section{4 自由振動に関する仮想仕事の原理}

円筒の自由振動解析に関する仮想仕事の原理は次のようである。

$$
\begin{gathered}
\iiint\left(\sigma_{\overline{x x}} \delta \varepsilon_{\overline{x x}}+\sigma_{\overline{\theta \theta}} \delta \varepsilon_{\overline{\theta \theta}}+\sigma_{\overline{z z}} \delta \varepsilon_{\overline{z z}}+\sigma_{\overline{x \theta}} \delta \varepsilon_{\overline{x \theta}}+\sigma_{\overline{\bar{z}}} \delta \varepsilon_{\overline{\theta z}}\right. \\
\left.+\sigma_{\overline{x z}} \delta \varepsilon_{\overline{x z}}\right) F d x d s d z-\rho \Omega^{2} \iiint \mathbf{U} \delta \mathbf{U} F d x d s d z=0
\end{gathered}
$$

ここで、のは密度、 $Q$ は円振動数である。なお、慣性項は次のよ うに表される。

$$
\begin{aligned}
\mathbf{U} \delta \mathbf{U}=\{(1+ & \left.\left.\frac{R}{\omega} \cos \alpha \cos \theta\right)^{2}+\left(\frac{R}{\omega} \sin \alpha\right)^{2}\right\} U \delta U \\
& -\frac{R}{\omega} \sin \alpha(U \delta V+V \delta U)+V \delta V+W \delta W
\end{aligned}
$$

また、Fは次のように表される。

$$
\begin{aligned}
F d V & =\mathbf{g}_{1} \cdot\left(\mathbf{g}_{2} \times \mathbf{g}_{3}\right) d x R d \theta d z \\
& =\left(1+\frac{R-z}{\omega} \cos \alpha \cos \theta\right)\left(1-\frac{z}{R}\right) d x R d \theta d z
\end{aligned}
$$

\section{5 変位関数}

Rayleigh-Ritz 法による解析を行うために、変位 $U 、 V 、 W$ につい て $x, z$ 方向に心゙き級数、 $\theta$ 方向にフーリエ級数をとると

$$
\begin{gathered}
U=f(x) \sum_{i=0}^{l} \sum_{j=0}^{m} \sum_{k=0}^{n}\left(a_{i j k} x^{i} z^{k} \cos j \theta+b_{i j k} x^{i} z^{k} \sin j \theta\right) \\
V=g(x) \sum_{i=0}^{l} \sum_{j=0}^{m} \sum_{k=0}^{n}\left(c_{i j k} x^{i} z^{k} \cos j \theta+d_{i j k} x^{i} z^{k} \sin j \theta\right) \\
W=h(x) \sum_{i=0}^{l} \sum_{j=0}^{m} \sum_{k=0}^{n}\left(e_{i j k} x^{i} z^{k} \cos j \theta+f_{i j k} x^{i} z^{k} \sin j \theta\right)
\end{gathered}
$$

となる。ここで、 $f(x) 、 g(x) 、 h(x)$ は幾何学的境界条件を満足する基 底関数、 $a_{i j k} 、 b_{i j k} 、 c_{i j k} 、 d_{i j k} 、 e_{i j k} 、 f_{i j k}$ は各項の未定係数である。

(14)式を無次元化して(11)式の仮想仕事の原理に代入することに より振動数方程式が導かれ、これを解くことにより無次元振動数パ

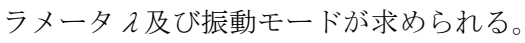

\section{3. 解析例}

\section{1 既存の解析例との無次元振動数パラメータ $\lambda$ の比較}

まず、既存の直円筒シェルの無次元振動数パラメータ $\lambda$ と本報告 の $\lambda$ を比較する。既存の直円筒シェルの $x$ 方向の幾何学的境界条件 は $f(x)=\cos (\pi x / l) 、 g(x)=\sin (\pi x / l) 、 h(x)=\sin (\pi x / l)$ で $x, z$ の項数 $l=0, n=3$ とし、円筒の板厚 $\mathrm{t}$ と円筒の半径 $\mathrm{R}$ との比 $\mathrm{t} / \mathrm{R}=0.1$ 、円筒の半径 $\mathrm{R}$ と円筒の長さ $l$ との比 $\mathrm{R} / l=1$ 、螺旋の半径 $\mathrm{a}$ と円筒の長さ $l$ との比 $\mathrm{a} / l=0$ 、 螺旋の高さ $\mathrm{c}$ と円筒の長さ $l$ との比 $\mathrm{c} / l=\infty 、 v=0.3$ とすると単純梁型 厚肉円筒シェルとなる。CTST (古典シェル理論)、FSDT（1 次せん 断変形理論）による $\lambda^{5)}$ との比較を表 1 に示す。ただし、表中の $j$ はフーリエ級数 $\theta$ の波数であり、入は次のようにおいている。

$$
\begin{aligned}
& \lambda^{2}=\rho t R^{2} \Omega^{2} / E_{p} \\
& \text { ここに、} E_{p} \text { は伸びこわさであり、以下のように表せる。 } \\
& E_{p}=E t /\left(1-v^{2}\right)
\end{aligned}
$$

表 1 より、FSDT と本報告の入にそれほどの違いがないことが分 かる。

表 1 既存の $\lambda$ との比較

\begin{tabular}{|c|c|c|c|}
\hline$j$ & CTST $^{5)}$ & FSDT $^{5)}$ & 本報告 \\
\hline 0 & 0.9882 & 0.9835 & 0.9835 \\
\hline 1 & 0.8938 & 0.8891 & 0.8888 \\
\hline 2 & 0.7457 & 0.7393 & 0.7384 \\
\hline 3 & 0.6913 & 0.6784 & 0.6772 \\
\hline 4 & 0.7800 & 0.7527 & 0.7520 \\
\hline
\end{tabular}

\section{2 螺旋状厚肉円筒の自由振動解析}

図 3 に解析に用いる片持ち螺旋状厚肉円筒の形状を示す。図 3 で は円筒の板厚 $\mathrm{t}$ と円筒の長さ $l$ との比 $\mathrm{t} / l=0.1$ 、円筒の半径 $\mathrm{R}$ と円筒 の長さ $l$ の比 $\mathrm{R} / l=0.2$ 、水平軸との傾斜角 $\alpha=\pi / 6$ 、螺旋状円の中心角 $\beta=\pi / 2$ 、ポアソン比 $v=0.3$ としている。この片持螺旋状円筒の自由振 動解析を、高次ラグランジ型補間関数を用いた三次元有限要素法 (高 次三次元要素と称す)、高次ラグランジ型補間関数を用いたアイソパ 
ラメトリックシェル有限要素法（高次シェル要素と称す）、二次元 Rayleigh-Ritz 法（前報告：薄肉理論と称す、なお、薄肉を対象とし ているため回転慣性も無視している)、及び、三次元 Rayleigh-Ritz 法（本報告：厚肉理論と称す）の 4 つの解析法で行い、無次元振動 数パラメータ $\lambda 、$ 及び、振動モードを比較・検討する。ただし $\lambda$ は 次のようにおいており、いずれの解析も倍精度で計算を行ってい る。

$$
\lambda^{2}=\rho t^{3} \ell^{2} \Omega^{2} /(12 D)
$$

ここに、Dは曲げ剛性であり、以下のように表せる。

$$
D=\frac{E t^{3}}{12\left(1-v^{2}\right)}
$$

なお、右端が固定の場合、三次元 Rayleigh-Ritz 法では幾何学的境 界条件の基底関数は $f(x)=g(x)=h(x)=x$ となる。

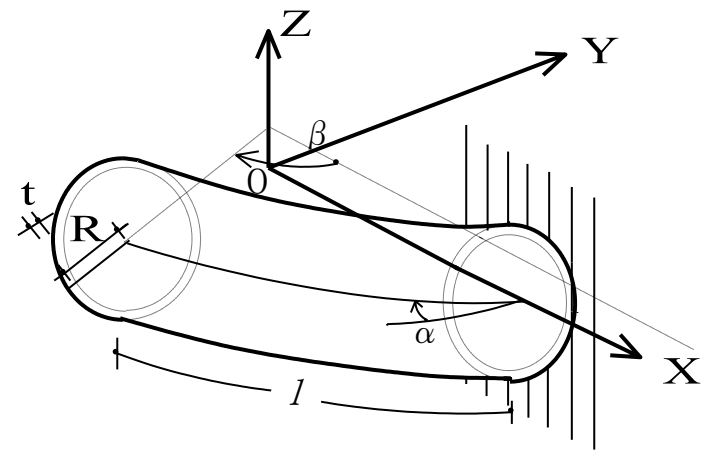

図 3 片持ち螺旋状厚肉円筒の形状

\section{2.1 高次三次元要素の $\lambda$ の収束状況}

分割数等の変化による $\lambda$ の収束状況を調べるために、高次三次元 要素で、分割数を螺旋座標 $(x, \theta, z)$ 方向に $4,4,1$ 分割し、 $(x, \theta, z)$ 方向に 補間節点数を $4,6,4 、 5,6,4 、 6,6,4$ と $(x)$ 方向だけ変化させた場合と、 $5,5,4 、 5,6,4 、 5,7,4$ と $(\theta)$ 方向だけ変化させた場合を表 2 に、 $5,6,3$ 、 $5,6,4 、 5,6,5$ と $(z)$ 方向だけ補間節点数を変えた場合と、一般的に用 いられる 27 節点要素 (補間節点数が三方向ともに $3(3 \times 3 \times 3))$ で、 分割数を螺旋座標 $(x, \theta, z)$ 方向に $10,8,2$ 分割した場合を表 3 に示す。

表 2 高次三次要素の $(x, \theta)$ 方向補間数の変化による $\lambda$ の収束状況

\begin{tabular}{|c|c|c|c|c|c|c|}
\hline 分割数 & $4,4,1$ & $4,4,1$ & $4,4,1$ & $4,4,1$ & $4,4,1$ & $4,4,1$ \\
\hline 補間数 & $4 \times 6 \times 4$ & $5 \times 6 \times 4$ & $6 \times 6 \times 4$ & $5 \times 5 \times 4$ & $5 \times 6 \times 4$ & $5 \times 7 \times 4$ \\
\hline 未知数 & 2880 & 3840 & 4800 & 3072 & 3840 & 4608 \\
\hline 1 & 0.39644 & 0.39588 & 0.39566 & 0.39615 & 0.39588 & 0.39587 \\
2 & 0.39768 & 0.39710 & 0.39689 & 0.39730 & 0.39710 & 0.39709 \\
3 & 0.92229 & 0.92186 & 0.92169 & 0.92196 & 0.92186 & 0.92185 \\
4 & 1.1777 & 1.1762 & 1.1757 & 1.1770 & 1.1762 & 1.1761 \\
5 & 1.4205 & 1.4195 & 1.4192 & 1.4209 & 1.4195 & 1.4195 \\
6 & 1.7341 & 1.7327 & 1.7323 & 1.7352 & 1.7327 & 1.7325 \\
7 & 1.8405 & 1.8390 & 1.8386 & 1.8503 & 1.8390 & 1.8382 \\
8 & 1.8954 & 1.8941 & 1.8937 & 1.9048 & 1.8941 & 1.8930 \\
\hline
\end{tabular}

表 2 の補間数 $6,6,4(6 \times 6 \times 4$ (高次三次元要素) と表 3 の分割数 10,8,2 (27 節点要素) は総未知変位数は 4800 で同じだが、 $\lambda$ の值 には若干の収束の違いが生じている。これより、薄肉ほどではない
が、厚肉においても一般的に用いられる 27 節点要素より高次三次 元要素の方が収束が良いことがわかる ${ }^{2)}$ 。なお、 27 節点要素の数值 積分には三方向とも 3 点の、高次三次元要素の数值積分には厚さ方 向には 6 点の、面内方向には 10 点の Gauss-Legendre 積分を用いて いる。表 2,3 より、補間数 $5 \times 6 \times 4$ で十分に収束していると考えられ る。

表 3 高次三次要素の $(z)$ 方向補間数の変化による $\lambda$ の収束状況

\begin{tabular}{|l|l|l|l|l|}
\hline 分割数 & $10,8,2$ & $4,4,1$ & $4,4,1$ & $4,4,1$ \\
\hline 補間数 & $3 \times 3 \times 3$ & $5 \times 6 \times 3$ & $5 \times 6 \times 4$ & $5 \times 6 \times 5$ \\
\hline 未知数 & 4800 & 2880 & 3840 & 4800 \\
\hline 1 & 0.39742 & 0.39669 & 0.39588 & 0.39583 \\
2 & 0.39864 & 0.39792 & 0.39710 & 0.39705 \\
3 & 0.92256 & 0.92241 & 0.92186 & 0.92183 \\
4 & 1.1827 & 1.1803 & 1.1762 & 1.1760 \\
5 & 1.4270 & 1.4237 & 1.4195 & 1.4193 \\
6 & 1.7471 & 1.7384 & 1.7327 & 1.7323 \\
7 & 1.9498 & 1.8666 & 1.8390 & 1.8371 \\
8 & 1.9950 & 1.9179 & 1.8941 & 1.8925 \\
\hline
\end{tabular}

\section{2.2 高次シェル要素の $\lambda$ の収束状況}

次に、薄肉あるいは中肉のシェル解析に良く用いられるアイソパ ラメトリックシェル要素について述べる。分割数等の変化による $\lambda$ の収束状況を調べるために、一般的に用いられる 9 節点要素（補間 節点数を $(x, \theta)$ 方向ともに $3(3 \times 3))$ で、分割数を $(x, \theta)$ 方向に 10,12 分割した場合と、高次シェル要素で、分割数を 4,4 とし $(x, \theta)$ 方向に 補間節点数を $6,6 、 6,7 、 7,6 、 7,7$ の 4 通りを用いた場合の $\lambda$ の収束 状況を表 4 に示す。一般的に用いられる 9 節点要素と、補間節点数 $7 \times 6$ は総未知数は 2400 で同じであるが、9 節点要素は若干、収束が 悪いことが分かる。高次シェル要素は総未知数が少なくても良い 入の值が求められている。なお、9 節点要素の積分には三方向とも 3 点の、高次シェル要素の数值積分には厚さ方向は 3 点の、面内方 向には 10 点の Gauss-Legendre 積分を用いている。表 3 より、補間 数 $6 \times 7$ で十分に収束していると考えられる。

表 4 高次シェル要素の分割数、補間数の変化による $\lambda$ の収束状況

\begin{tabular}{|c|c|c|c|c|c|}
\hline 分割数 & 10,12 & 4,4 & 4,4 & 4,4 & 4,4 \\
\hline 補関数 & $3 \times 3$ & $6 \times 6$ & $6 \times 7$ & $7 \times 6$ & $7 \times 7$ \\
\hline 未知数 & 2400 & 2000 & 2400 & 2400 & 2880 \\
\hline 1 & 0.39484 & 0.39438 & 0.39434 & 0.39436 & 0.39431 \\
2 & 0.39672 & 0.39605 & 0.39599 & 0.39602 & 0.39595 \\
3 & 0.92642 & 0.92513 & 0.92497 & 0.92489 & 0.92468 \\
4 & 1.1731 & 1.1710 & 1.1709 & 1.1713 & 1.1711 \\
5 & 1.4198 & 1.4173 & 1.4172 & 1.4174 & 1.4172 \\
6 & 1.7301 & 1.7245 & 1.7239 & 1.7254 & 1.7248 \\
7 & 1.8513 & 1.8305 & 1.8291 & 1.8313 & 1.8299 \\
8 & 1.9024 & 1.8847 & 1.8831 & 1.8854 & 1.8837 \\
\hline
\end{tabular}

\section{2.3 厚肉理論 (本報告) の $\lambda$ の収束状況}

次に厚肉理論(三次元 Rayleigh-Ritz 法)の項数変化による $\lambda$ の収束 状況を示す。表 5 において $7 \times 7 \times 3$ は $(x, \theta, z)$ 方向の項数 $(=6, m=6, n=2)$ を、819 は総未知係数を表している。数值積分は厚さ方向には厚肉 
表 5 三次元 Rayleigh-Ritz 法の項数による $\lambda$ の収束状況

\begin{tabular}{|c|c|c|c|c|c|c|}
\hline 項数 & $7 \times 7 \times 3$ & $7 \times 7 \times 4$ & $7 \times 7 \times 5$ & $6 \times 6 \times 4$ & $7 \times 7 \times 4$ & $8 \times 8 \times 4$ \\
\hline 未知係数 & \multicolumn{1}{|c|}{819} & 1092 & 1365 & 792 & 1092 & 1440 \\
\hline 1 & 0.39750 & 0.39674 & 0.39670 & 0.39724 & 0.39674 & 0.39644 \\
2 & 0.39874 & 0.39796 & 0.39792 & 0.39851 & 0.39796 & 0.39765 \\
3 & 0.92324 & 0.92271 & 0.92269 & 0.92311 & 0.92271 & 0.92248 \\
4 & 1.1816 & 1.1775 & 1.1774 & 1.1789 & 1.1775 & 1.1769 \\
5 & 1.4241 & 1.4200 & 1.4198 & 1.4209 & 1.4200 & 1.4195 \\
6 & 1.7386 & 1.7328 & 1.7324 & 1.7341 & 1.7328 & 1.7321 \\
7 & 1.8649 & 1.8373 & 1.8354 & 1.8388 & 1.8373 & 1.8365 \\
8 & 1.9158 & 1.8921 & 1.8906 & 1.8934 & 1.8921 & 1.8915 \\
\hline
\end{tabular}

のため 10 点の、面内方向は 15 点の Gauss-Legendre 積分を用いてい る。なお、 $\theta$ 方向の積分は、三角関数の積分の危険性を考えて全領 域を 2 分割し、それぞれに数值積分を適用している。積分区間を分 割することによって総未知係数が増えることはない。

表 5 より、厚肉理論は $7 \times 7 \times 4$ の項数であれば $\lambda$ の值は十分に収束 していると考えられる。

\section{2.4 それぞれの解析法による無次元振動数パラメータ $\lambda の$ 比較}

板厚と板の長さの比を $t / l=0.01,0.05,0.1,0.2$ の 4 通りをとり、高次 三次元要素、高次シェル要素、薄肉理論、厚肉理論で解析した $\lambda$ を 表 6〜9 で比較する。薄肉 $(t / l=0.01)$ の場合、 4 解析法ともほとんど似 た值となったが、板厚が大きくなる $(t / l=0.05,0.1,0.2)$ につれて薄肉理

表 6 様々な解法による $\lambda$ の值 $(t / l=0.01: t / R=0.05)$

\begin{tabular}{|c|c|c|c|c|}
\hline 解析法 & 三次元 & シェル & 薄肉理論 & 厚肉理論 \\
\hline 分割数 & $4,4,1$ & 4,4 & & \\
\hline 項数等 & $5 \times 8 \times 3$ & $5 \times 8$ & $10 \times 10$ & $10 \times 10 \times 3$ \\
\hline 未知数 & 4032 & 2240 & 570 & 1710 \\
\hline 1 & 0.20149 & 0.20127 & 0.20082 & 0.20096 \\
\hline 2 & 0.20211 & 0.20527 & 0.20154 & 0.20161 \\
\hline 3 & 0.38129 & 0.38140 & 0.37983 & 0.38007 \\
\hline 4 & 0.38688 & 0.39358 & 0.38569 & 0.38571 \\
\hline 5 & 0.63308 & 0.63021 & 0.63325 & 0.63162 \\
\hline 6 & 0.63792 & 0.65113 & 0.63817 & 0.63638 \\
\hline 7 & 0.80041 & 0.80247 & 0.79977 & 0.79890 \\
\hline 8 & 0.81183 & 0.81083 & 0.81155 & 0.81070 \\
\hline
\end{tabular}

論の入の值だけが他の値と違ってきている。これは、薄肉理論は板 厚が厚くなると生じる回転慣性あるいはせん断変形の影響を考慮し ていないためだと考えられる。薄肉理論に関して、入の許容誤差範 囲（\{薄肉理論の $\lambda$ の値一厚肉理論の $\lambda$ の值 $\} /$ 厚肉理論の $\lambda$ の値） を $5 \%$ 以内とすると、この解析例では、薄肉理論は $t / 1=0.1$ で 6 次の $\lambda$ までが、 $t / l=0.2$ だと 2 次までが許容誤差範囲に入る。よって、無 次元振動数パラメータ $\lambda$ を求める場合、低次の $\lambda$ あ゙れば、相当大 きな厚肉でも薄肉理論が適用できるものと思われる。

なお、薄肉 $(t / l=0.01)$ 場合、総未知変位数（総未知係数）は、高次 三次元要素(4032)、高次シェル要素(2240)、厚肉理論(1710)、薄肉 理論(570)の順に少なくなっている。板厚が厚くなっても総未知変位 数 (総未知係数) は同じ傾向である。解析時間については、数值積 分の次数あるいはマトリックスの疎密等の違いによっても変わるが、 一般的には総未知変位数(総未知係数)が少ない方が解析時間も速い。
表 7 様々な解法による $\lambda$ の值 $(t / l=0.05: t / R=0.25)$

\begin{tabular}{|c|c|c|c|c|}
\hline 解析法 & 三次元 & シェル & 薄肉理論 & 厚肉理論 \\
\hline 分割数 & $4,4,1$ & 4,4 & & \\
\hline 項数等 & $5 \times 7 \times 4$ & $6 \times 8$ & $10 \times 10$ & $8 \times 8 \times 4$ \\
\hline 未知数 & 4608 & 2800 & 570 & 1440 \\
\hline 1 & 0.35656 & 0.35530 & 0.35907 & 0.35695 \\
\hline 2 & 0.35854 & 0.35755 & 0.36117 & 0.35887 \\
\hline 3 & 0.88199 & 0.88466 & 0.89265 & 0.88210 \\
\hline 4 & 0.93168 & 0.92854 & 0.95388 & 0.93183 \\
\hline 5 & 1.0416 & 1.0393 & 1.0687 & 1.0412 \\
\hline 6 & 1.2605 & 1.2621 & 1.2823 & 1.2593 \\
\hline 7 & 1.3888 & 1.3886 & 1.4218 & 1.3891 \\
\hline 8 & 1.4446 & 1.4491 & 1.4924 & 1.4462 \\
\hline
\end{tabular}

表 8 様々な解法による $\lambda$ の值 $(t / l=0.1: t / R=0.5)$

\begin{tabular}{|c|c|c|c|c|}
\hline 解析法 & 三次元 & シェル & 薄肉理論 & 厚肉理論 \\
\hline 分割数 & $4,4,1$ & 4,4 & & \\
\hline 項数等 & $5 \times 6 \times 4$ & $6 \times 7$ & $10 \times 10$ & $7 \times 7 \times 4$ \\
\hline 未知数 & 3840 & 2400 & 570 & 1092 \\
\hline 1 & 0.39588 & 0.39434 & 0.40195 & 0.39674 \\
\hline 2 & 0.39710 & 0.39599 & 0.40308 & 0.39796 \\
\hline 3 & 0.92186 & 0.92497 & 0.94888 & 0.92271 \\
\hline 4 & 1.1762 & 1.1709 & 1.2106 & 1.1775 \\
\hline 5 & 1.4195 & 1.4172 & 1.4727 & 1.4200 \\
\hline 6 & 1.7327 & 1.7239 & 1.7699 & 1.7328 \\
\hline 7 & 1.8390 & 1.8291 & 2.0561 & 1.8373 \\
\hline 8 & 1.8941 & 1.8831 & 2.0959 & 1.8921 \\
\hline
\end{tabular}

表 9 様々な解法による $\lambda$ の值 $(t / l=0.2: t / R=1.0)$

\begin{tabular}{|c|c|c|c|c|}
\hline 解析法 & 三次元 & シェル & 薄肉理論 & 厚肉理論 \\
\hline 分割数 & $4,4,1$ & 4,4 & & \\
\hline 項数等 & $5 \times 6 \times 5$ & $5 \times 8$ & $10 \times 10$ & $7 \times 7 \times 5$ \\
\hline 未知数 & 4800 & 2880 & 570 & 1365 \\
\hline 1 & 0.44314 & 0.44297 & 0.46165 & 0.44439 \\
\hline 2 & 0.44757 & 0.44521 & 0.46821 & 0.44914 \\
\hline 3 & 0.94633 & 0.95465 & 1.0536 & 0.94792 \\
\hline 4 & 1.3003 & 1.2921 & 1.3938 & 1.3020 \\
\hline 5 & 1.5375 & 1.5435 & 1.7421 & 1.5379 \\
\hline 6 & 1.8083 & 1.8054 & 1.9425 & 1.8097 \\
\hline 7 & 2.6985 & 2.6705 & 3.2115 & 2.6986 \\
\hline 8 & 2.8917 & 2.8314 & 3.4724 & 2.8872 \\
\hline
\end{tabular}

\section{2.5 振動モード}

板厚と板の長さの比を $t / l=0.01,0.05,0.1,0.2$ の 4 通りをとり、高次 三次元要素、高次シェル要素、薄肉理論、厚肉理論で解析した 1 次 から 8 次までの振動モードと $\lambda$ の值を図 $4 \sim 7$ に示す。なお、振動 モードは最大変位を生じる点を基準の大きさとし、それに比例して 任意の点を描いた。ただし、 $t / l=0.05,0.1,0.2$ の低次の振動モードは 見分けがつきにくいために基準の大きさを数倍にして描いた。

図 4 の板厚が薄い $(t / l=0.01)$ 場合、高次シェル要素の振動モードだ けが若干異なっている。高次シェル要素において、対どうしで振動 モードが異なる（1 次と 2 次、 5 次と 6 次）場合は、お互いの $\lambda$ の 值が近いために入れ替わったものと考えられるが、他の解析法の振 動モードと明らかに異なる（3 次、4 次）場合の原因は分かってい 


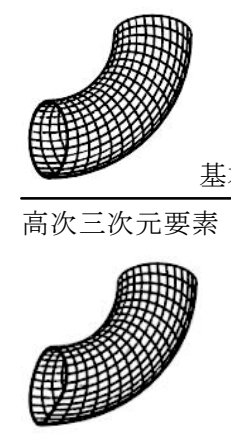

0.20149
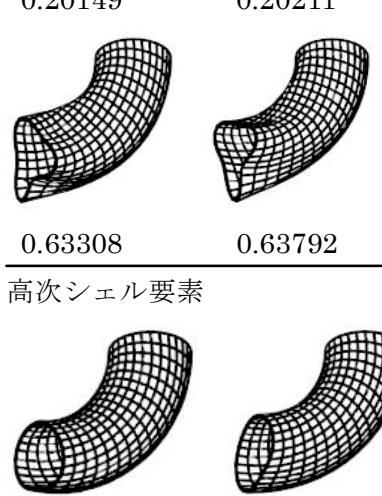

0.63792
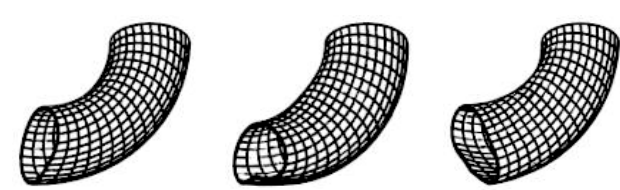

0.20127

0.20527

\begin{abstract}
0.38140
\end{abstract}
0.39358
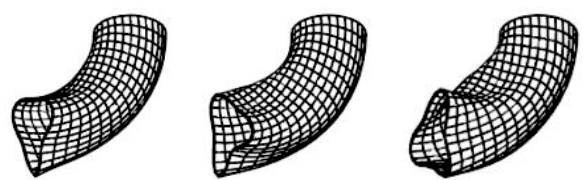

0.80247
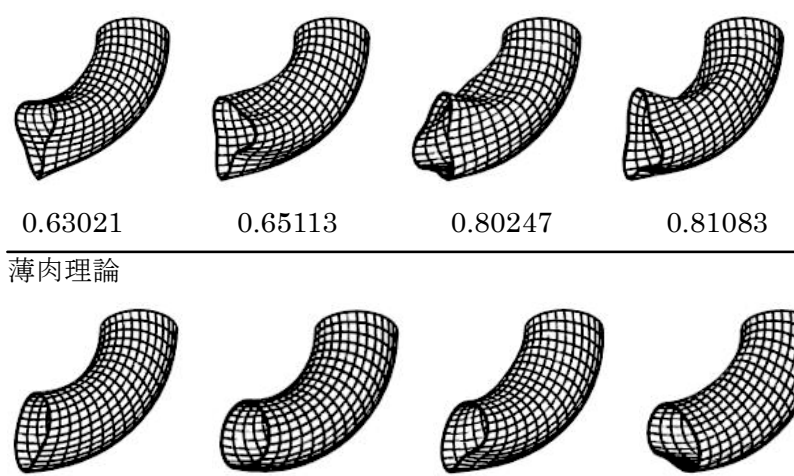

0.65113

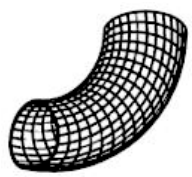

0.20082

0.20154

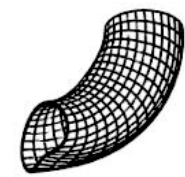

0.37983

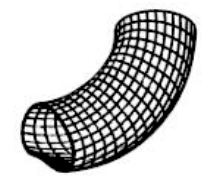

0.38569
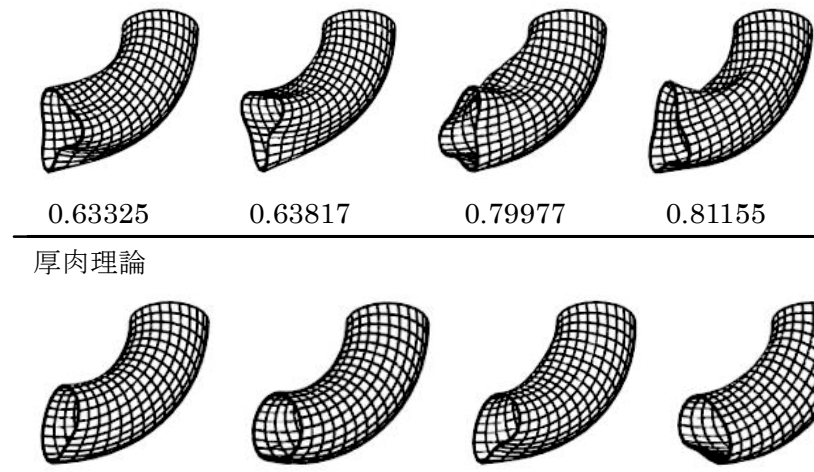

0.63817

0.79977

0.81155
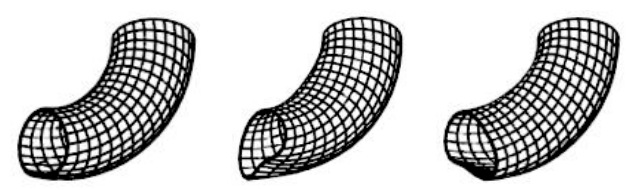

0.20096

0.20161

0.38007

0.38571
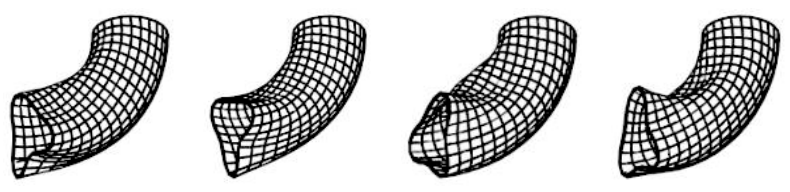

$0.63162 \quad 0.63638$

0.79890

0.81070

図 4 無次元振動数パラメータ $\lambda$ と振動モード $(t / l=0.01: t / R=0.05)$
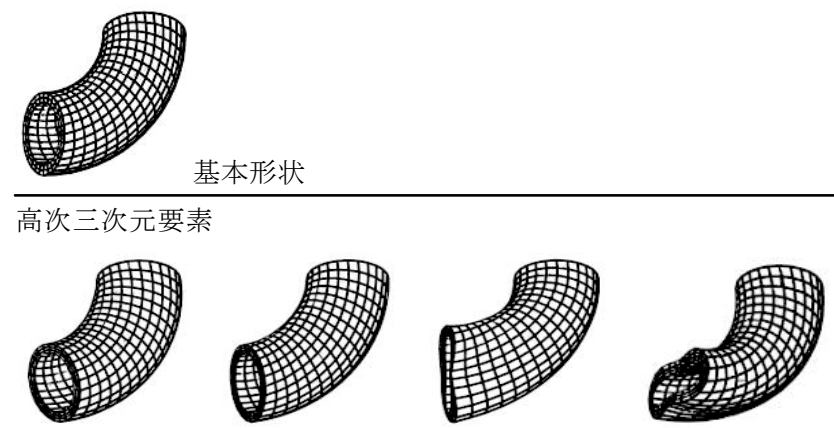

0.35656

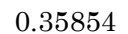

0.88199

0.93168
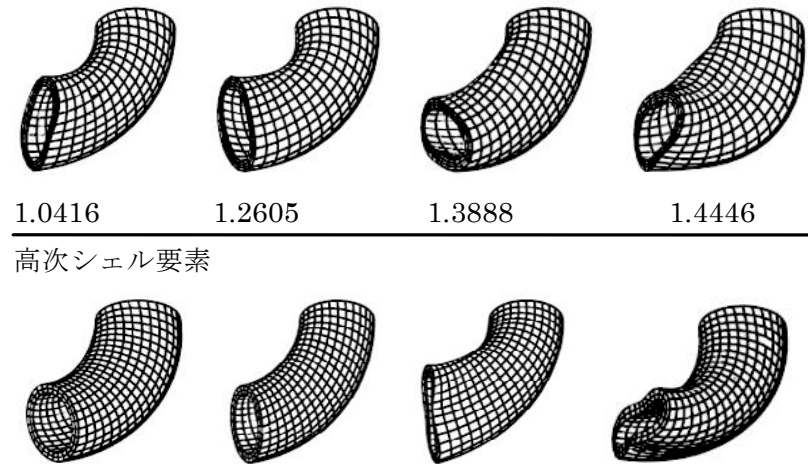

1.2605

1.3888

1.4446
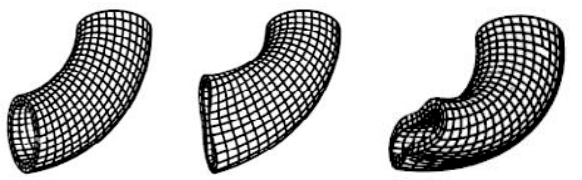

0.35530

0.35755

0.88466

0.92854
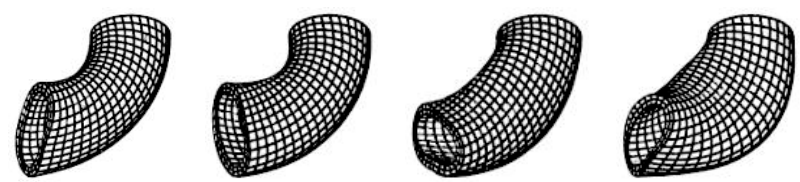

1.0393

1.3886

1.4491
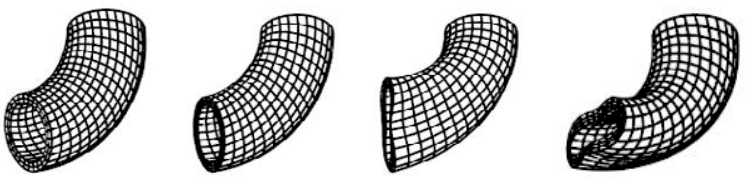

0.35907

0.36117

0.89265

0.95388
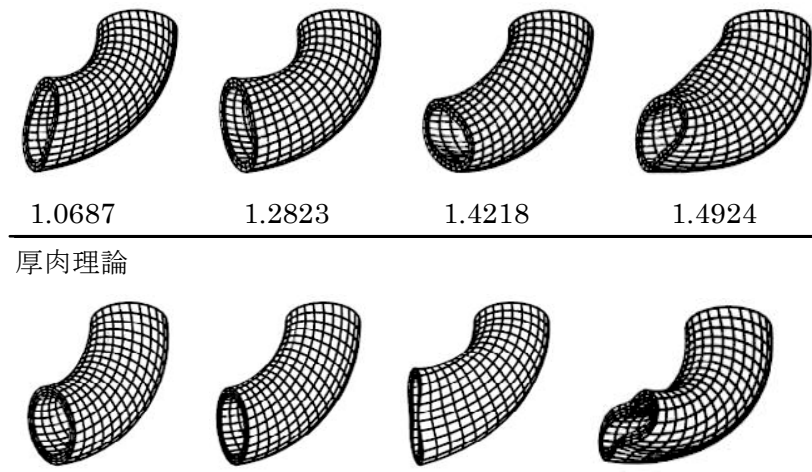

1.2823

1.4218

1.4924
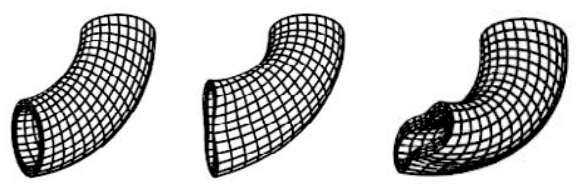

0.35695

0.35887

0.88210

0.93183
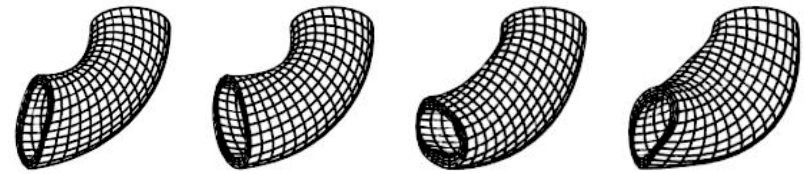

図

1.2593

1.3891

1.4462

図 5 無次元振動数パラメータ $\lambda$ と振動モード $(t / l=0.05: t / R=0.25)$ 

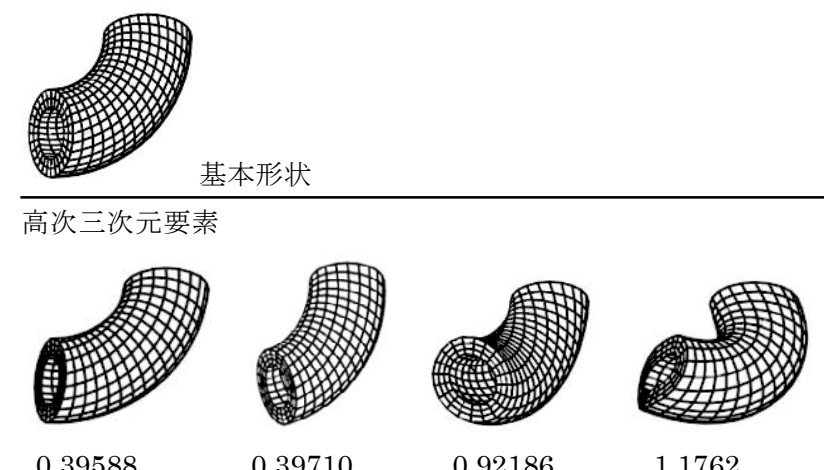

0.39588

0.39710

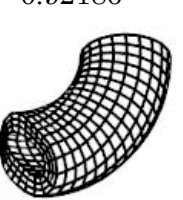

1.1762
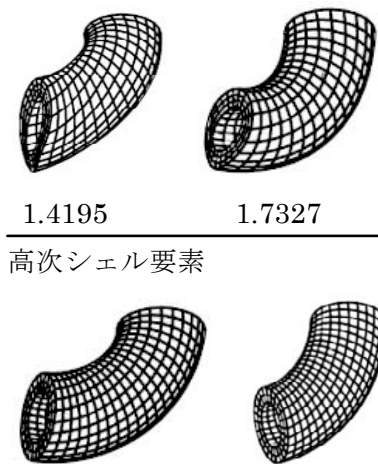

1.7327

1.8390
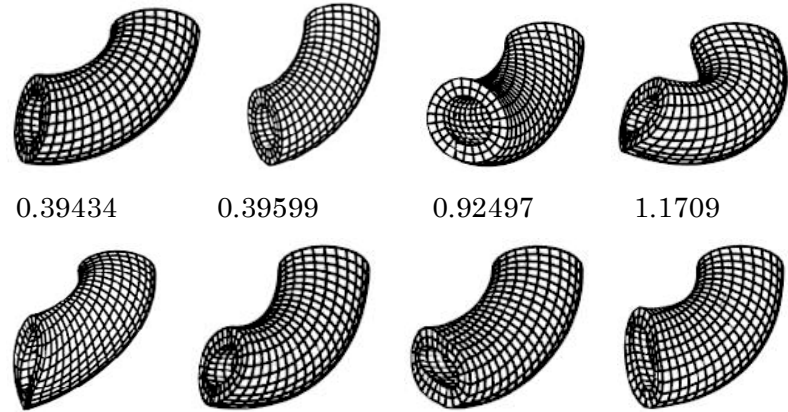

0.39599

\begin{abstract}
0.92497
\end{abstract}
1.1709
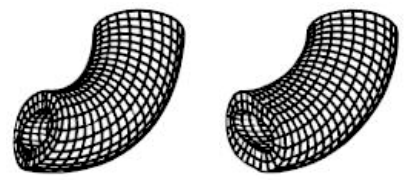

1.7239

1.8291
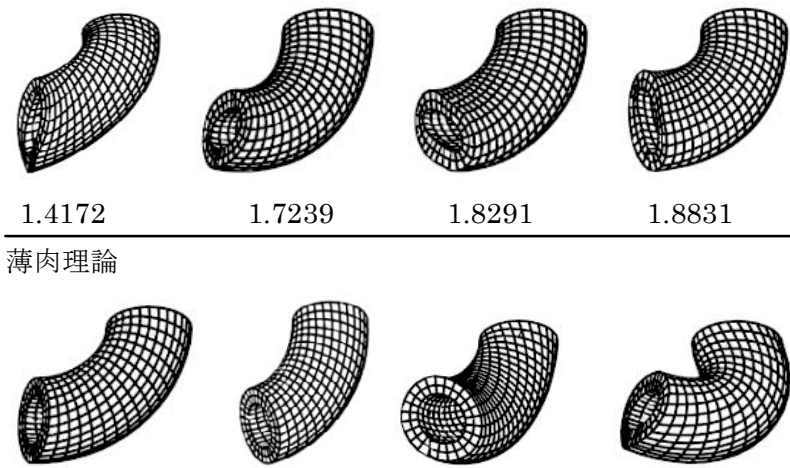

0.40308
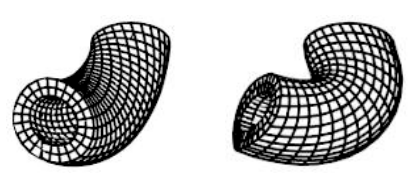

0.40195

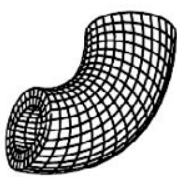

0.94888

1.2106
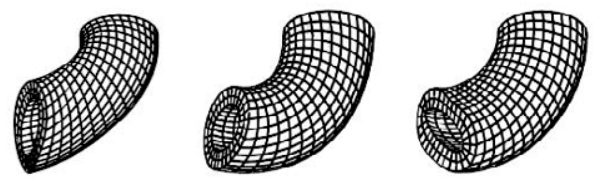

1.4727

1.7699

2.0561

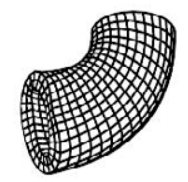

2.0959
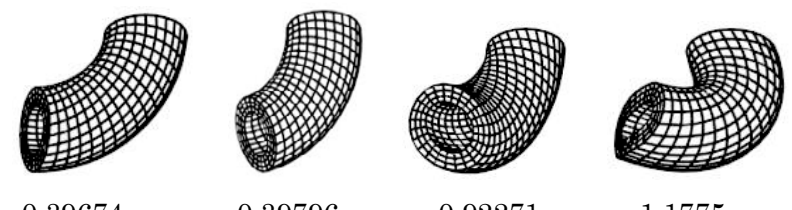

0.39674

0.39796

0.92271

1.1775
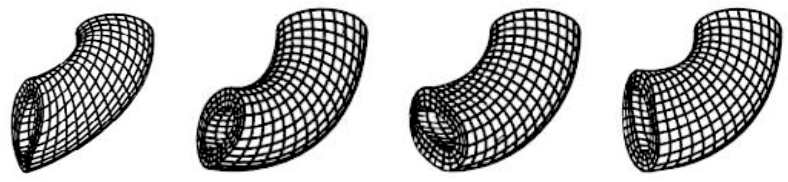

$1.4200 \quad 1.7328$

1.8373

1.8921

図 6 無次元振動数パラメータ $\lambda$ と振動モード $(t / l=0.1: t / R=0.5)$
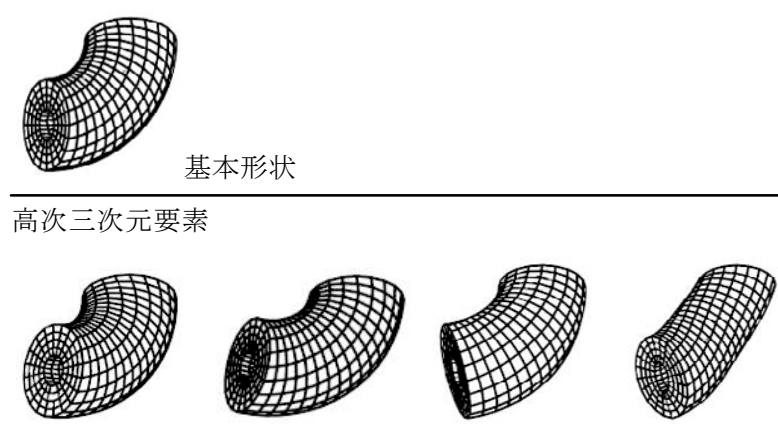

0.44314

0.44757

0.94633

1.3003
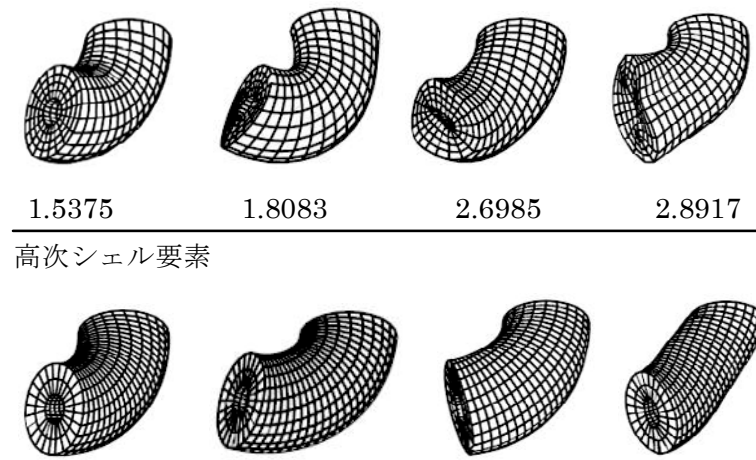

1.8083

2.6985

2.8917
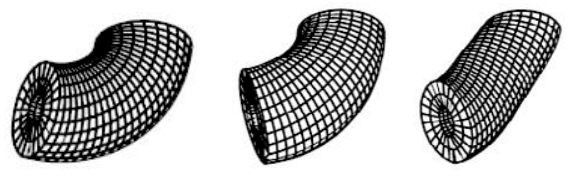

0.44297

0.44521

0.95465

1.2921
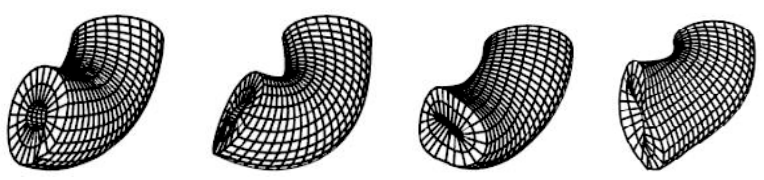

$\frac{1.5435}{\text { 薄肉理論 }}$

1.8054

2.6705

2.8314
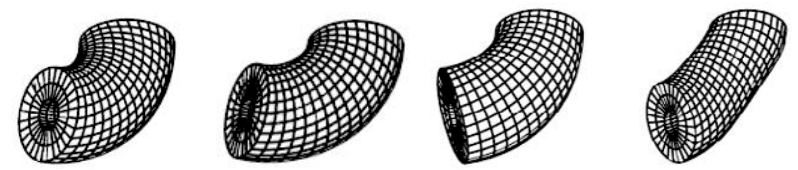

0.46165

0.46821

1.0536

1.3938
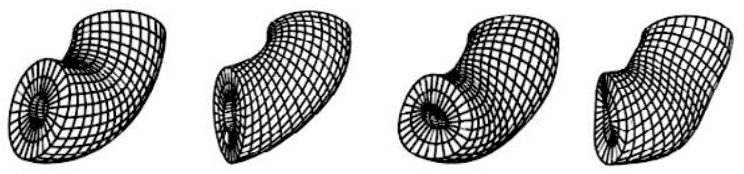

1.7421

1.9425

3.2115

3.4724
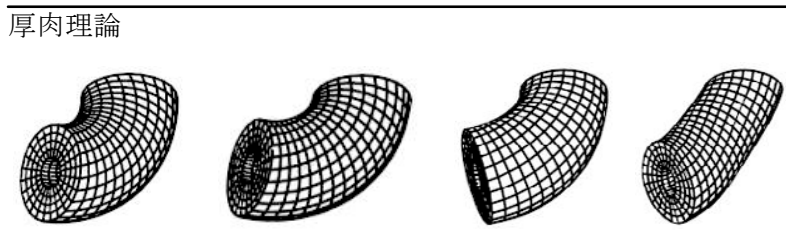

0.44439

0.44914

0.94792

1.3020
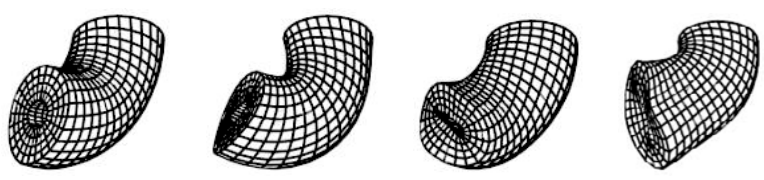

$\frac{1}{\text { 図 }}$

1.8097

2.6986

2.8872

図 7 無次元振動数パラメータ $\lambda$ と振動モード $(t / l=0.2: t / R=1.0)$ 
ない。図 5 の板厚が中程度 $(t / l=0.05)$ 、あるいは、図 6 の板厚が厚い $(t / l=0.1)$ 場合は 4 解析法の振動モードには変わりがない。図 7 の板 厚が極端に厚い $(t / l=0.2)$ 場合は薄肉理論の高次の振動モード（6 次、 7 次、8 次）が他の解析法と明らかに異なっている。

\section{4. むすび}

本報告では、前報告で導いた螺旋軸上の厚肉円筒のひずみ一変位 関係式を用いて、螺旋状厚肉円筒の自由振動に関する仮想仕事の原 理を定式化した。次に、片持ち螺旋状厚肉円筒の自由振動解析を三 次元 Rayleigh-Ritz 法により行い、無次元振動数パラメータ ス、およ び振動モードを求めた。さらに、前報告で求めた薄肉理論による Rayleigh-Ritz 法、高次ラグランジ型補間関数を用いた三次元アイソ パラメトリック有限要素、及び、高次ラグランジ型補間関数を用い たアイソパラメトリックシェル要素で片持ち螺旋状厚肉円筒の自由 振動解析を行い、比較した結果、次のような結論を得た。

1) 薄肉 $(t / l=0.01: t / R=0.05)$ の場合、 1 次から 8 次までの無次元振動 数パラメータ $\lambda$ は 4 解析法とも同じような值に収束した。

2) 厚肉 $(t / l=0.05,0.1: t / R=0.25,0.5)$ 及び極厚肉 $(t / l=0.2: t / R=1.0)$ の場 合、板厚が厚くなるにつれて、薄肉理論による解析法の 1 次か ら 8 次までの無次元振動数パラメータ $\lambda は$ は他の解析法と異な る值に収束した。これは薄肉理論には板厚が厚くなると生じる、 せん断変形や回転慣性の影響が考慮されていないからだと思 われる。

3）薄肉理論による $\lambda$ は、この解析例では厚肉 $(t / l=0.1)$ で 6 次まで、 極厚肉 $(t / l=0.2)$ で 2 次までが他の解析法の $\lambda$ と $5 \%$ 以内となり、 薄肉理論は、低次の $\lambda$ を求める場合であれば、厚肉にも使用可 能であると考えられる。

4） 4 解析法のうち、薄肉理論の Rayleigh-Ritz 法が最も未知数が少 なく、次に厚肉理論による Rayleigh-Ritz 法、高次シェル要素、 三次元要素の順となった。

5) 薄肉 $(t / l=0.01)$ の場合、高次シェル要素の振動モードは他の三つ の解析法と若干違う振動モードとなった。

6) 厚肉 $(t / l=0.05,0.1)$ の場合、振動モードは 4 解析法とも全く同じ となった。

7) 極厚肉 $(t / l=0.2)$ の場合、この解析例では薄肉理論の低中次 $(1 \sim 5$ 次）の振動モードは他の解析法と同じとなり、高次（6〜8 次） の振動モードは異なった。よって、薄肉理論は低中次の振動モ ードを求める場合であれば、厚肉にも使用可能であると考えら れる。

よって、本報告で提案した厚肉理論による解析法（三次元 Rayleigh-Ritz 法) は、高次三次元要素や、高次シェル要素より総未 知数が少なく、薄肉から極厚肉までの振動解析において問題等は生 じていないため有効な方法だと考えられる。

また、薄肉理論による振動解析法も板厚の厚さの適用範囲は広く、 有効な方法と考えられる。

さらに、高次三次元要素、高次シェル要素（高次シェル要素は薄 肉の振動モードを除いて）とも、この振動解析においては十分に有 効な方法と考えられる。
参考文献

1) Robert E. Kielb, Arthur W. Leissa, James C. MacBain, Kelly S. Carney : Joint Research Effort on Vibrations of Twisted Plates, Phase I Final Resurts, NASA Reference Publication 1150, pp.1-97, 1985.

2）板倉和則 : Rayleigh-Ritz 法を用いた螺旋状薄肉円筒の自由振動解析，日本建 築学会構造系論文集, Vol.78, No.683, pp.81-89, 2013.1

3）板倉和則,須田量哉,有木伸也,山城友哉:厚肉螺旋曲板要素を用いた極薄肉螺 旋曲板の自由振動解析, 日本建築学会構造系論文集, No.605, pp.111-118, 2006.7

4）熟津久一郎,宮本博,その他: 有限要素法ハンドブック I 基礎編, pp.410-416, 培風館, 1981 .

5）鈴木勝義,山田元,成田吉弘,齊藤俊 : シェルの振動入門, コロナ社, pp.89, 1996.

(2013年 6 月14日原稿受理，2014年 1 月15日採用決定） 